\title{
斜面崩壊に至るスライドの加速モデル
}

\section{A Model for Acceleration of Slide to Slope Failure}

\author{
林 拙 郎* 川邉 洋* \\ Setsuo HAYASHI \\ Hiroshi KAWABE
}

\begin{abstract}
A basic model of the slide to slope failure is derived from three assumptions. The basic slide equation in tertiary creep is given as following: $\dot{v}=a v+b v^{2}$. Here, $v$ is the velocity of displacement, $\dot{v}$ the time differential of $v, a$ and $b$ the constants. This equation expresses the acceleration mechanism of soil mass to slope failure and is available as a model of slope failure prediction. For friction coefficient $(\mu)$ the $\mu-v$ relationship obtained shows the same tendency as the result of Dieterich, that is, $\mu$ decreases exponentially if $v$ increases. Lastly, the mutual relation of $\mu, v$ and displacement $(l)$ become clear by use of coefficients $a$, $b$ and other physical parameters.
\end{abstract}

キーワード: 地すべり・崩壊発生, 斜面崩壊の予知, 第 3 次クリープ, スライド方程式

\section{1.はじめに}

斜面崩壊の予知は，地震や火山噴火予知とならんで重 要な課題の一つである ${ }^{15,17)}$ 。斜面崩壊の予知の可能性は 次のような考え方に基づいている。

地すべりや規模の大きい山崩れでは，外力がせん断破 壊強度を上まわった場合でも，必ずしもすぐ崩壊が始ま るのではなく,クラックの拡大から実際の崩壊までには, 移動に伴う時間を必要とする。例えば，コンクリートや 土質実験等で扱うテスト・ピースのようなものの場合に は，瞬間的であったり，ほんの数秒で破壊が終了する。 しかし, これが数百メー夕の斜面では, たと元急傾斜で あったとしても崩壊までには数日から数十日を要する場 合が多い。実際の斜面崩壊では，せん断応力は通常破壊 強度とほほ同程度か, それよりわずかに上まわる程度で あるから, 当然移動速度も遅く, 崩壊までに時間がかか ることになる。クラック発生からの移動速度は, 普通 1 日 当たり数 $\mathrm{mm}$ から数 $\mathrm{cm}$ の速度であり, 崩壊までの数日 〜数十日という日数もよく見られる例である。ここに崩 壊予知の可能性があり, 避難の時間も生ずる。

ところで, 最近は斜面等の下端部に法面カットをする 機会も多く, この場合には, テストピース等の破壊実験 と同様，外力は，ほほ一定に保たれることになり，破壊 強度を少し上まわる程度の外力によって崩壊が進行する ことになる。以下では, 法面カットの場合のように, 外 力が土の強度をわずかに上まわっていて，かつ変化しな

* 三重大学生物資源学部
いような比較的単純な条件の下で崩壞に伴うスライドの 加速モデルを示す。

\section{2. これまでのスライド方程式}

崩壊過程を移動速度の増加過程としてみると，最初は 1 日当たり数 $\mathrm{cm}$ というほとんど目には見えないような 移動速度から始まり，最後は急激な加速を伴って崩㐭す るという過程を示すことが多い。このような加速現象が どのようなメカニズムによって発生するのかいまのとこ ろはっきりしておらず, 種々のモデル2-4,9,12-14,16-18) が提 案されているのが現状である。ここでは, 次のような崩 壊発生過程の土体加速モデルを考察する。

\section{1 林らのスライド方程式}

林ら ${ }^{4)}$ は砂をつめた土層に水を注入することによって 行った崩壊実験より

(1) ある程度の移動量 $l$ がないと崩壊は発生しない。

(2) 移動速度が小さくても崩壊は発生しない。 という観察結果を得た。このことより, 移動速度 $v$ と移 動量 $l$ という phase 上で考察を行い, 実験デー夕を

$$
v=f(l)
$$

という phase 上で整理した。この結果, 第 3 次クリープ の崩壊過程には次のような 2 つの段階があることが示さ れた4)。

第 I段階: $v=v_{0}+a l, \quad \dot{v}=a v$

$$
1=\left(v_{0} / a\right)\left(e^{a t}-1\right)
$$


第 II段階: $v=v_{0} e^{b\left(l-l_{0}\right)}, \quad \dot{v}=a v^{2}$

$$
l-l_{0}=\frac{1}{b} \ln \frac{t_{r}-t_{0}}{t_{r}-t}
$$

ここに, $\dot{v}: v$ の時間微分, $v_{0}$ : 移動速度 $v$ の各段階での 初期值, $a, b$ 係数, $l_{0}$ : 移動量 $l$ の第 II段階の初期值, $t$ : 時間， $t_{0}$ : その初期值， $t_{r}$ : 崩壊時間である。第 II段階の (2) 式は斉藤式として知られている ${ }^{13)} 。$

第 I 段階の (1) 式は, $v, l$ が $t$ に対して指数曲線的に増 加し, 第 II段階の (2) 式は, $t$ が $t_{r}$ に接近すると加速的に $l, v$ が大きくなる。第 I 段階第 II段階を連続したものと して表すために, 林らは次のスライド方程式を提案し $た^{5,7)}$ 。

$$
\frac{d v}{d t}=a v+b v^{2}
$$

ここに, $a, b:$ 新しく導入した定数である。(3) 式は, $t=$ $t_{r}$ で $v=\infty$ となるように解を設定することができ, 次式 で表される7)。

$$
\begin{aligned}
& v=\frac{a / b}{\exp \left(a\left(t_{r}-t\right)\right)-1} \\
& \exp \left(a\left(t_{r}-t_{0}\right)\right)=\left(a+b v_{0}\right) /\left(b v_{0}\right) \\
& l-l_{0}=\frac{1}{b} \ln \frac{z_{r}-z_{0}}{z_{r}-z} \\
& z_{r}=\exp \left(a t_{r}\right), z_{0}=\exp \left(a t_{0}\right), z=\exp (a t) \\
& v=\left\{\left(a+b v_{0}\right) / b\right\} \exp \left(b\left(l-l_{0}\right)\right)-a / b
\end{aligned}
$$

ここに, $t_{0}: t$ の初期值, $v_{0}: v$ の初期値である。(3), (4) 式 は移動量 $l$ と移動速度 $v$ とを用いた $v \sim l$ phase 上での 解析結果に基づいて提案されたものである。この方法は， 軌道上の速度を調べる運動学的な方法であり, 力学的な 帰結やモデルより導かれたものではない。

福直 ${ }^{2)}$ おび Voight ${ }^{17,18)}$ は,

$$
d v / d t=a v^{n}
$$

のタイプの式を提案している。ここに, $a, n$ 定数であ る。この式は, 地震予知の基本式として Shol $z^{15)}$ の著書 に紹介されている。上式は通常 (3) 式の一部を表している ものと考えられる。

\section{2 納口らのグライド加速モデル}

納口ら ${ }^{10,11)}$ は，なだれにおけるグライドの数理的な加 速モデルとして次式を示した。

$$
\frac{d v}{d t}=a \frac{\varepsilon_{0}}{\varepsilon_{1}}\left(1+\frac{\varepsilon_{1}}{\varepsilon_{0}} v\right) v
$$

ここに, $\varepsilon_{0}, \varepsilon_{1}, a$ : 定数である。納口は, 底面の真の接 触面積を想定した内的変数を導入して, 駆動力 $f$ と抵抗 力 $R$ とが釣り合うという仮定より出発して上式を導い た。
これまで，スベリ現象の加速モデルは，破壊まで含め ると多くの論文があるが, 崩壊現象を合理的に説明する ものは少なかった。この点, 納口らのモデルは一部に数 理的モデルを含んでいるが，画期的な考察を含んでいる。

\section{3. 土体の加速モデル}

斜面上に発生する崩壊は, 大規模なものでも小規模な ものであってもほとんどは, すべり面の形成とそれらに 伴うすべり面上でのすべり現象と考えることができる。 ここではピーク強度を少し超える一定外力が作用してい る状態を考え, その後の移動にともなって摩擦抵抗力が 低下し, 同時に移動速度が増加するというような機構を 考察する。

\section{1 駆動力 $f$ と抵抗力 $R$}

斜面上の土体にすべり面が形成された状態を考える。 上の層は重力によって駆動力 $f$ を受け, 下の安定な層と の境界ではこれに抵抗する力 $R$ が逆方向に作用する。斜 面上の土体にキレツなどが入って動き始めるには， $f$ と $R$ がほとんど等しいか, ほんの少しでも駆動力 $f$ が抵抗 力 $R$ を上まわればよいのである。

さて，このような駆動力 $f$ が与えられるとし，その $f$ は変化しないものとする。このように考えると, 後述す るように最終段階を除いてすべりの移動速度は小さく， 加速度も小さいので, 駆動力 $f$ と抵抗力 $R$ とは静的に釣 合条件を満たし

$$
f-R=0
$$

と考えることができる。上式は, グライドの加速モデル において導入された in der Gand and Zupanicic ${ }^{8)}$ や納 口10)の仮定である。

\section{2 抵抗力 $\boldsymbol{R}$}

次に，すべり面について考える。図ー1(a)のような山 腹にキレツが入り移動が始まっているとする。このよう な場合, 底面にはすべり面が形成されていると考えるこ とができ，底面を拡大すれば図ー1(b)のようになる。底 面では図ー1 (b) のように一部は接触しているだけであり， 一部は破壊したクズ状の物質があるかもしれない。この ような底面を模式化して図ー2のように表す。

図一2の斜線部は破壊された物質を示し，斜線のない ところは未破壊物質同士の接触を表している。しかし, 後者の部分においても全く破壊されたものがない訳では なく，移動している以上わずかな薄い破壊物が含まれて いると考えるべきであろう。こう考えると図-2 は, さら に図一 3 のような平均的に厚さ $\delta$ なるすべり層をはさん で上部の土塊が移動しているとみることができる。

以上のように, $\delta$ なるすべり層を考えると, 図一 3 のよ うに底面には摩擦抵抗力が作用し, その上部の剪断層内 
(a)

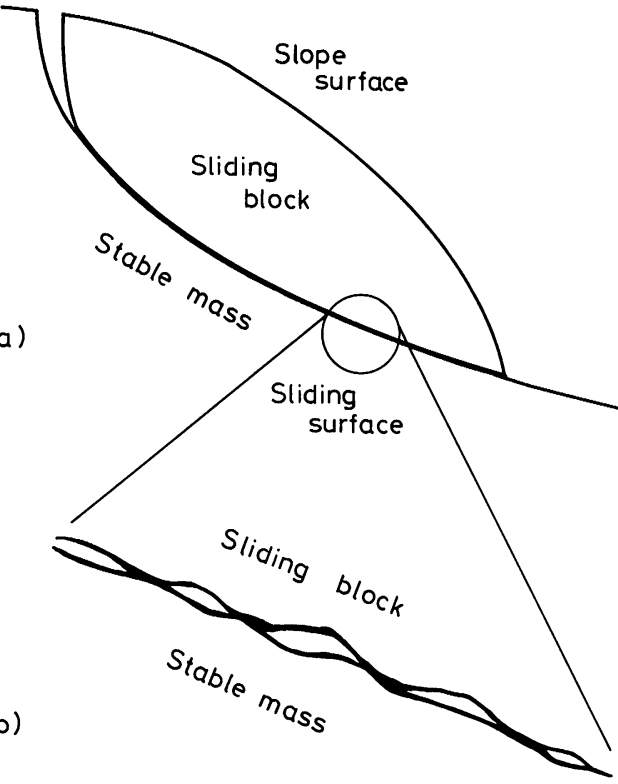

图ー1 すべり面とその上を移動する土塊

(a) 形成されたすべり面と土塊

(b) すべり面の拡大図

Slope failure with sliding surface

(a) Sliding surface formed on a stable mass

(b) Microscopic view of the sliding surface

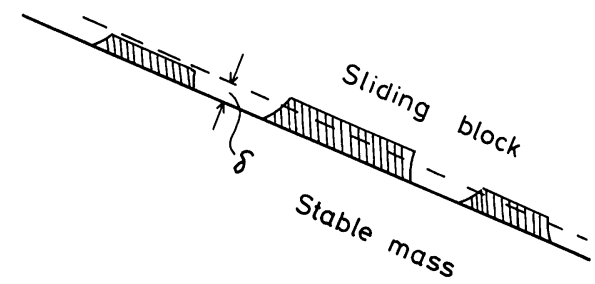

图ー2 すべり面上の破壊部と非破壊部 Schematic model of sliding surface

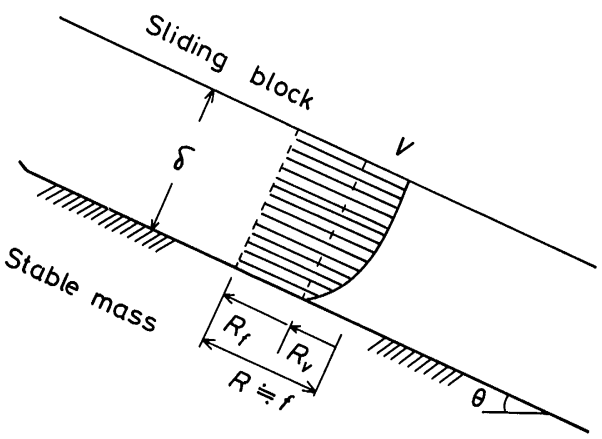

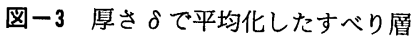
Normalized sliding layer with average thickness $(\delta)$ of sliding surface
にも摩擦に伴う運動量の伝達が行われるものと考えるこ とができる19)。したがって,この層内は速度勾配を持つこ とが考えられ，ここでは速度に比例する抵抗を考えるこ とができる。

このように考えると, 抵抗力 $R$ は, 摩擦抵抗力 $R_{f}$ と 粘着力の抵抗力 $R_{c}$, 粘性抵抗力 $R_{v}$ の和であり

$$
R=R_{f}+R_{c}+R_{v}
$$

と表すことができる。抵抗力 $R$ の各成分は，摩擦係数 $\mu$, 粘着力 $c$, 粘性係数 $\eta$ を導入することによって, 次式 のようになる。

$$
R=\mu W \cos \theta+c A+\eta A v / \delta
$$

ここに, $W$ : すべり面上の重量, $A$ : 底面樌, $v$ : 移動速 度, $\delta:$ 剪断層の厚さ, $\theta$ : 傾斜角である。上式は, なだれ 発生において in der Gand and Zupanicic $\left.{ }^{8}\right)$ が提案した 式と同様の式である。異なるところは, 粘着力 $c$ が入っ ていることである。土や軟岩の場合, 破壊初期には最大 摩擦強度と粘着力をもつが, すべりが始まると粘着力は 低下する。今回は取扱いを簡単にするために, $c$ は初期破 壊時 $\left(t=t_{0}\right)$ のみに值をもつが,すべりが始まった時点で $c=0$ となるものとする。

\section{3 加速機構}

土塊が動き始めて, 土のピーク強度をすぎると土の摩 擦強度は低下を始めるのであるが, 図一4のように駆動 力 $f$ が一定であり, それと抵抗力 $R$ が釣合っているの で, (12) 式は一定值とならなければならない。土塊が動き 始めると (12) 式右辺第 1 項は徐々に低下し, かわりに第 3 項が増加することになる。ここのメカニズムは次のよう に考える。

まず, 摩擦係数 $\mu$ の移動量 $l$ に対する変化が剪断層の 厚さ $\delta$ に逆比例して減少するとして次式を仮定する。

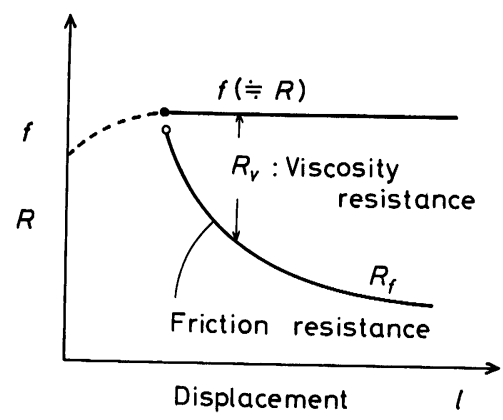

园-4 移動開始に伴う駆動力 $f$ と抵抗力 $R$ の相互の関係

Driving force $(f)$ and components of resisting force $(R)$ for displacement 
$d \mu / d l=-k / \delta$

次に, 剪断層 $\delta$ の変化が移動量 $l$ に関係するとして次式 を仮定する。

$$
d \delta / d l=b \delta
$$

ここに, $b, k$ は比例定数である。ここでは, クズ状の破 壊物質は土塊が移動することによって生じ, その厚さが 増加すると摩擦係数が上式に従って減少すると考える。 粘性係数 $\eta$ に関してはここでは変化しないものとする。

ところで, 駆動力 $f$ は時間的に変化しないとしている ので, 抵抗力 $R$ は

$$
d R / d t=0
$$

であり，結局次式のようになる。

$\frac{d \mu}{d t} W \cos \theta-\eta A v \frac{1}{\delta^{2}} \frac{d \delta}{d t}+\eta A \frac{1}{\delta} \frac{d v}{d t}=0 \cdots \cdots \cdots(15)$

一方，(14)，(13) 式より

$d \delta / d t=b \delta v$

$d \mu / d t=-k v / \delta$

を得る。(16)，(17) 式を (15) 式に代入すると次式のようにな る。

$$
\begin{aligned}
& \frac{d v}{d t}=\left(\frac{k W}{\eta A} \cos \theta\right) v+b v^{2}=a v+b v^{2} \\
& a=\frac{k W}{\eta A} \cos \theta=\frac{k}{\eta} \sigma \ldots \ldots \ldots \ldots \ldots \ldots \ldots \ldots \ldots \ldots \ldots \ldots \ldots
\end{aligned}
$$

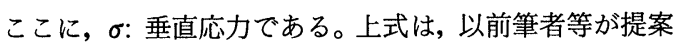
したスライドの基本方程式 (3) 式である。このモデルから みれば崩壊過程は, 摩擦抵抗型の抵抗形態から粘性抵抗 型の抵抗形態への移行過程と見なすことができる。

\section{$3.4 \mu, \delta$ の状態と移動型}

さて，ここで得られた(15), (18).式より次のことがわか る。

(1) $\mu=$ 一定で $\delta=$ 一定の場合

$$
v=\text { 一定 }
$$

となり，定常クリープを表す。

(2) $\mu \neq$ 一定, $\delta=$ 一定の場合

$$
b=0
$$

となり，第 I 段階を表す。

(3) $\mu=$ 一定, $\delta \neq$ 一定の場合

$$
a=0
$$

となり，第II段階（斉藤タイプ）を表す。

(4) $\mu \neq$ 一定, $\delta \neq$ 一定の場合

第 I 段階, 第II段階を含む (18) 式,つまり第 3 次ク リープの式が成立する。

\section{4. 考察}

スライドモデルは，スライド初期の緩慢な動きから，崩 壊までの加速状態を説明できるものでなければならない し, この加速モデルが力学的なものとなるためには, こ れまで知られている剪断結果等との対応が説明できる必 要がある。前節では (13)，(14) 式を(15) 式に代入することに よって，スライド方程式 (18) 式を求めた。本節では，(13), (14) 式を抵抗力 $R$ の式に代入することによって移動機構 を考察する。続いて摩擦係数と移動速度, それに摩擦強 度等の関係を明らかにする。

\section{$4.1 \delta, \mu, v_{0}$ と $v \sim l$ 関係式}

(14) 式は, 初期条件を $l=l_{0}$ で $\delta=\delta_{0}$ とすると次式を 得る。

$$
\delta=\delta_{0} \exp \left(b\left(l-l_{0}\right)\right)
$$

上の (20) 式を (13) 式に代入すると

$$
d \mu / d l=-\left(k / \delta_{0}\right) \cdot \exp \left(-b\left(l-l_{0}\right)\right) \cdots \cdots \cdots \cdots(21)
$$

となり, $l=l_{0}$ で $\mu=\mu_{0}$ とすると次式を得る。

$$
\mu=\mu_{0}-\frac{k}{b \delta_{0}}\left\{1-\exp \left(-b\left(l-l_{0}\right)\right)\right\} \cdots \cdots \cdots \cdots(22)
$$

破壊の初期 $\left(t=t_{0}\right)$ に発生する速度, 摩擦係数を $v_{0}, \mu_{0}$ とすると，(12) 式より $v_{0}$ は

$$
\begin{aligned}
& v_{0}=\frac{\delta_{0}}{\eta A} \Delta f \ldots \ldots \ldots \ldots \ldots \ldots \ldots \ldots \ldots \\
& \Delta f=f-c A-\mu_{0} W \cos \theta
\end{aligned}
$$

となる。ここに, $\Delta f$ は破壊の初期に土の強度を超えた力 の大きさである。上の (20) 式，(22) 式を(12) 式に代入すると 次式のようになる。

$$
\begin{aligned}
v= & \frac{\delta_{0}}{\eta A}\left(\Delta f+\frac{k}{b \delta_{0}} W \cos \theta\right) \cdot \exp \left(b\left(l-l_{0}\right)\right) \\
& -\frac{1}{b} \frac{k W}{\eta A} \cos \theta \ldots \ldots \ldots \ldots \ldots \ldots \ldots \ldots \ldots \ldots \ldots \ldots \ldots \ldots \ldots \ldots \ldots \ldots \ldots \ldots \ldots
\end{aligned}
$$

ここで(19) 式，(23) 式の関係を用いると次式を得る。

$$
v=\frac{a+b v_{0}}{b} e^{b\left(l-l_{0}\right)}-\frac{a}{b}
$$

(26) 式は, 既にこれまで得られている(7) 式と同様の式で ある。(26) 式は剪断層の厚さ $\delta$ と摩擦係数を移動量 $l$ を用 いて直接抵抗力の式 (12) 式に代入して求めたものである。 スライドの $v \sim l$ 式である (26) 式は, (4) 式, (5) 式, (6) 式よ り既に求められていたが，このように $\mu(l), \delta(l)$ の 関係式を (10) 式，(12) 式に直接代入しても求められる。

さて，(7) 式では初期速度 $v_{0}$ の内容が明らかでなかっ たが，(23) 式より $\Delta f$ に比例していることがわかる。ま た, $v_{0}$ は係数, $a, b$ に無関係であることが, (23) 式よりわ 
かるが，これまでの実験結果でもそのことは示されてい る6)。これまで $f$ が破壊強度を上まわると初期移動速度 $v_{0}$ が与えられると考えてきた ${ }^{6)}$ が， $\Delta f$ は (24) 式で与えら れるので，このモデルはこのことをよく表すことができ る。破壊直前の状態を考えると $v=0$ であり, 土の最大強 度 $s_{0}$ は (12) 式より

$$
s_{0}=\left(c A+\mu_{0} W \cos \theta\right) / A
$$

と置くことができ, (23) 式, (24) 式より $v_{0}$ は, 次のように表 すことができる。

$$
\begin{aligned}
& v_{0}=\frac{\delta_{0} S_{0}}{\eta}\left(\frac{f}{s_{0} A}-1\right)=\frac{\delta_{0} S_{0}}{\eta}\left(\frac{1-F_{s}}{F_{s}}\right) \\
& F_{s}=s_{0} A / f
\end{aligned}
$$

ここに, $F_{s}$ は安全率であり, $v_{0}$ が安全率の関数であるこ とを示している。したがって, 何等かの形で土の強度が 低下するか，駆動力が増加して安全率が 1 を下まわると 初期移動速度 $v_{0}$ が与えられ，もし駆動力 $f$ がそのままて あるならば, その後の加速機構はスライドの基本式に よって移動することになる。

以上より, $v \sim l$ 関係, 初期速度 $v_{0}$ の内容が示された。

\section{$4.2 \mu \sim v$ 関係}

ここでは, 摩擦係数 $\mu$ について考察する。Dieterich ${ }^{11}$ は, 岩石の摩擦実験より摩擦係数 $\mu$ が速度の増加, ある いは固着時間の減少に対して低下するとしている。ここ では, 本モデルで $\mu$ と $v$ の関係を調べるために (26) 式と (22) 式から $l$ を消去し, また(19) 式, (23) 式, (27) 式の関係を 用いると, $\mu$ は $v$ 関数として次式で表される。

$$
\begin{aligned}
& \mu=\mu_{0}-\mu_{k}\left(1-\frac{a+b v_{0}}{a+b v}\right) . \\
& \mu_{k}=\frac{k}{b \delta_{0}}=\frac{a}{b v_{0}} \frac{s_{0}}{\sigma}\left(\frac{1-F_{s}}{F_{s}}\right)
\end{aligned}
$$

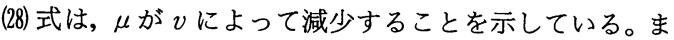
た $\mu_{k}$ は，(29) 式のような重要な諸因子と結びついている ことがわかる。(29) 式は変形すると

$$
\frac{a}{b v_{0}}=\mu_{k} \frac{\sigma}{s_{0}}\left(\frac{1-F_{s}}{F_{s}}\right)^{-1} \text {. }
$$

を得る。実験に乾燥した砂を用いる場合には $s_{0}=\sigma \mu_{0}$ で あり

$$
\frac{a}{b v_{0}}=\frac{\mu_{k}}{\mu_{0}}\left(\frac{1-F_{s}}{F_{s}}\right)^{-1}=\frac{\mu_{k}}{\mu_{0}}\left(\frac{\Delta f}{s_{0} A}\right)^{-1}
$$

となる。

図ー5 は砂を用いた崩壊実験の場合 ${ }^{6)}$ であり, $a /\left(b v_{0}\right)$ と $\left(1-F_{s}\right) / F_{s}$ とが逆比例の関係にあると認められる。 この実験では，明瞭な崩壊が必ずしも認められず，係数 $b$ の值にバラツキが見られるためにデータが少し散乱し ているが, (31) 式が概略成立しているとみることができる。

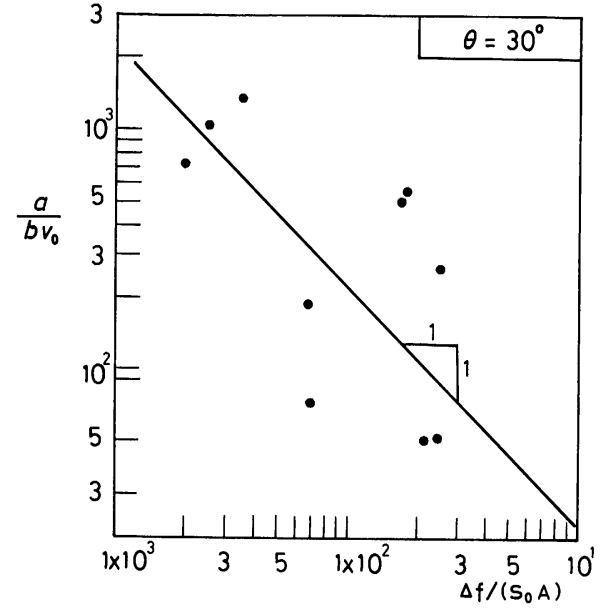

目ー5 崩壊時における $a / b v_{0}$ と $\Delta f /\left(s_{0} A\right)$ の関係 $a / b v_{0}$ versus $\Delta f /\left(s_{0} A\right)$ at the failure experi. ment in the sand slope

This experiment has been made by using the box shear test with $23 \times 25 \times 10 \mathrm{~cm}$ on slope of board

\section{3 安居山崩壞の場合}

以上のようにして求められる $v \sim l$ 関係， $\mu \sim v$ 関係を 安居山崩壊(6)にいて調べる。条件は

$$
\begin{aligned}
& \sigma=38.6\left(\mathrm{tf} / \mathrm{m}^{2}\right), \quad \mu_{0}=0.488, \quad c=1\left(\mathrm{tf} / \mathrm{m}^{2}\right), \\
& s_{0}=19.8\left(\mathrm{tf} / \mathrm{m}^{2}\right), \quad \theta=27.3^{\circ}, \quad F_{s}=0.99, \\
& a=4.5 \times 10^{-2}(1 / \mathrm{d}), \quad b=0.68(1 / \mathrm{m}), \\
& v_{0}=1.1 \times 10^{-2}(\mathrm{~m} / \mathrm{d})
\end{aligned}
$$

として, 平面すべり面をもつ斜面とすると, 図 -6 が求め られる。図ー6は，実際の崩壊例であるが， $\mu \sim v$ 関係は 初期の部分を除くと Dieterich ${ }^{1)}$ の岩石に対する測定結 果とよく似た結果となっている。筆者の速度データの範 囲は $1.2 \times 10^{-5} \sim 1.2 \times 10^{-3}(\mathrm{~cm} / \mathrm{s})$ である。

\section{4 静的釣合式の妥当性}

これまでは，すべり状態において加速度は小さいもの として (10) 式が成立すると仮定した。しかし，たとえ小さ くても加速がある限り，力が作用するのでその影響を調 べる必要がある。加速度が作用するとき, 厳密には (10) 式 は次のように表される。

$$
f-R=\frac{W}{g} \frac{d v}{d t}
$$

ここに, $g$ : 重力加速度である。(32) 式の $R$ に (12) 式を代入 すると次式のようになる。

$$
f=\mu W \cos \theta+c A+\eta \frac{A}{\delta} v+\frac{W}{g} \frac{d v}{d t}
$$

ここで, (33) 式で $v$ が小さいとき, 右辺第 4 項が無視で きることを示す。まず, (20), (22) 式より求められる $\delta, \mu$ を 


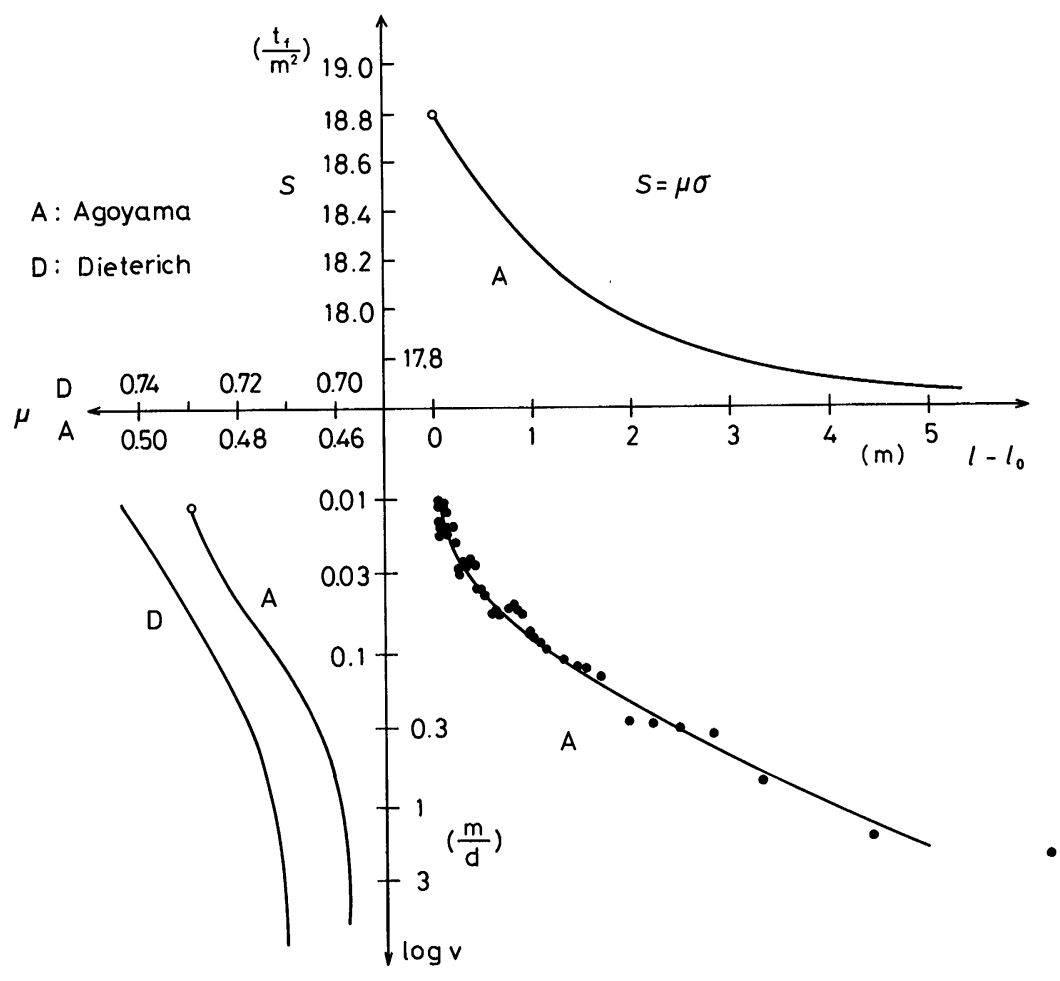

図-6 移動に伴う摩擦抵抗力 $s$ と移動量 $l$, 移動速度 $v$, 摩擦係数 $\mu$ の相互の関係 Mutual relation of friction force $(s)$ per unit area, displacement $(l)$, friction coefficient $(\mu)$, and displacement velocity $(v)$

(33) 式に代入し，(26) 式の場合と同様に(19)，(23)，(24) 式の関 係を用いると $l, v$ に関する次式が得られる。

$$
\begin{aligned}
& h e^{b\left(l-l_{0}\right)} \frac{d v}{d t}+v-\frac{a+b v_{0}}{b} e^{b\left(l-l_{0}\right)}+\frac{a}{b}=0 \\
& h=\delta_{0} W /(\eta A g)
\end{aligned}
$$

(34) 式の第 1 項を無視した式が先の (26) 式である。速度 $v$ あるいは移動量 $l$ が大きくなるときには，(34) 式左辺第 1 項は無視できないのであるが, この項が意味をもつ值と して

$$
h e^{b\left(l-l_{0}\right)}=10^{-2} \quad(\text { day }-\mathrm{m} \text { 単位 })
$$

を設定する。この值は, $v$ を崩壊の前日〜当日に対して $v$ $\approx 1(\mathrm{~m} / \mathrm{d})$ とし,$d v / d t も$ 概略 $1\left(\mathrm{~m} / \mathrm{d}^{2}\right)$ として, $v$ に 影響を与える大きさを $v$ に対して 2 桁程度下にとったも のである。h $e^{b\left(l-l_{0}\right)}$ の值がこの值より大きくなると, 第 1 項が無視し得なくなるものと考元る。

安居山の場合, $h$ は $h=3.3 \times 10^{-11}$ (day $-\mathrm{m}$ 単位 $)$ で あるので，(35) 式の解として

$$
l-l_{0}=29 \mathrm{~m}
$$

を得る。この値は安居山斜面のヒズミ量として約 30\%程
度の值である。安居山崩壊では, 全日数 40 日の内, 崩壊 の前日でも $l-l_{0}=7(\mathrm{~m}), v=2(\mathrm{~m} / \mathrm{d})$ 程度であり, $l$ $-l_{0}=29(\mathrm{~m})$ という值は, 通常の斜面崩壊からいえば, まさに崩壊の直前の值であり,この程度まで, 先の (18) 式 が使用可能であることを示している。崩壊予測の分野に おいては，これまで崩壊当日のかなり直前まで予測式を 用いて検討した例があり，このことは以上の解析の妥当 性を裏付けている。

以上より, (34) 式の係数 $h$ が非常に小さいので, $l, v$ が 余程大きくない限り, (34) 式第 1 項は無視できることにな る。

ところで, (34) 式第 1 項を無視する場合には崩壊時の速 度として計算上無限大もあり得る。したがって, 崩壊時 $\left(t=t_{r}\right)$ に仮想的に $v \rightarrow \infty$ とすることは, 崩壊予測等に おいては便宜上妥当な考え方であると思われる。 Voight ${ }^{17,18)}$ は, 崩壞予測にあたって崩壊時に有限な速度 を用いるべきであるとしている。ところが，静的な釣合 を前提にすると, このように明確に崩壊を定義すること が可能となる。 


\section{5. 結 論}

斜面崩壊の加速モデルを摩擦抵抗の減少と粘性抵抗の 増大という二つの機構から説明した。本論文では, 三つ の仮定を設けることによって，既に提案されているスラ イドの基本式を導くことができた。スライドの基本式は, 第 3 次クリープの最初から崩壊までを含んでおり, 崩壊 予知モデルとしても重要である。

仮定した式は, 駆動力 $f$ と抵抗力 $R$ の釣合式と (13) 式, (14) 式である。 $f=R$ という式は重要であり, 崩壊直前を 除いて仮定としても無理のないものであることが示され た。仮定の (13) 式 (14) 式は今後検討しなければならないが, 結果として既に得られているスライドの加速式7に一致 していることと, 摩擦係数が移動速度と固着時間に依存 するとしたDieterich ${ }^{1)} の \mu \sim v$ 関係と同様な結果を与 えること, さらに, 係数パラメータ $a /\left(b v_{0}\right)$ と超過駆動 力 $\Delta f$ の関係が砂を用いた実験結果と一致していること から, ほほ妥当な仮定とみられる。今回は, 問題を簡単 にするために, 粘着力 $c$ が移動開始と同時にゼロまで低 下するとし, 破壊クズ状物質の性質を表す粘性係数 $\eta$ は 一定であるとして検討した。この考え方に従えば，摩擦 係数が低下するということによって第 3 次クリープから 崩壊まで説明できることになる。

移動速度 $v$ と時間 $t$ の関係は, 先の (4) 式によって与 えられる。もし, 係数 $a, b$ を移動データより予め求める ことができれば, 崩壊発生時期を予知することが可能と なる。

\section{参考文献}

1) Dieterich, J. H.: Time-dependent friction and the mechanics of stick-slip, Pure and Applied Geophysics, 116 , pp. $790-806,1978$

2 ) Fukuzono, T: A new method for predicting the failure time of a slope, Proc. 4th Int. conf. and Field Workshop on Landslides, Tokyo, pp. 145-150, 1985

3 ) 林拙郎・駒村富士弥・朴甫源: 斜面崩壊発生時期の予測に
ついて, 地すべり, 24 (4) , pp. 11〜 18, 1988 a

4) Hayashi, S., Park, B. W., Komamura, F. and Yamamori, T.: On the forecast of time to failure of slope (II) Approximate forecast in the early period of the tertiary creep, J. Jpn. Landslide Soc. 25 (3), pp. 11 $-16,1988 \mathrm{~b}$

5 ）林拙郎・山森幹・朴甫源・駒村富士弥: 斜面崩壊の経時進 行過程について一第 3 次クリープの統一式, 第 100 回日 林論, pp. $661 \sim 664,1989$

6 ）林拙郎・西川公也: 斜面上の一面剪断実験と崩壊進行過 程の特徵, 第 102 回日林論, pp. 577-580, 1991 a

7) Hayashi, S. and Yamamori, T.: Basic equation of slide in tertiary creep and feature of its parameters, J. Jpn. Landslide Soc. 28 (1), pp. 17-22, 1991b

8 ) in der Gand, H. R. and Zupanicic, M.: Snow gliding and avalanches, IAHS-AISH publication, No. 69, pp. 230-242, 1965

9 ) Kawamura, K.: Methodology for landslide prediction, Proc. 11th Int. Conf. Soil Mech. Found. Eng'g, San Francisco, 3, pp. 115-158, 1984

10）納口恭明: グライド現象の数理モデル，防災センター研 報, No. 30, pp. 189-206, 1983

11）納口恭明・山田穣・五十嵐高志: 全層なだれにいたるグラ イドの加速モデル，防災センター研報, No. 38, pp. 169-180, 1986

12）大村寛・土屋智: すべり面拡大モデルによるクリープ現 象の解析, 地すべり, $25(1)$, pp. 1-6, 1988

13）斉藤迪孝: 第 3 次クリープによる斜面崩壊時期の予知, 地すべり, 4 (3) , pp. 1-8, 1968

14) Saito, M: Evidential study on forecasting occurrence of slope failure, 応用地質調查所研報, No. 1, pp. 1-23, 1979

15) Scholz, C. H.: The mechanics of earthquakes and faulting, pp. 353-358, Cambridge university press, 1990

16) Varnes, D. J.: Time-deformation relations in creep to failure of earth materials, Proc. 7th Southeast Asian Geotech. Conf. 2, pp. 107-130, 1982

17) Voight, B.: A method for prediction of volcanic eruptions, Nature, 332 (March), pp. 125-130, 1988

18) Voight, B.: A relation of describe rate-dependent material failure, Science, 243 (I3, Jan.), pp. 200-203, 1989

19) Vyalov, S. S.: Stability of slope of deep excavations and natural slopes, Proc. 8th Int. Conf. Soil Mech. Found. Eng'g, pp. 301-302, 1973

20）渡正亮: 安居山（福井）の地すべり運動, 施工技術, 6 (7)， pp. 109-112, 1973

（原稿受理日 平成 6 年 6 月 8 日） 
地すべり斜面形成過程からみた現在の地すべり地塊の構造及び運動の解釈

一高知県谷の内地すべりを例として一

「地すべり」Vol. 32, No. 2 (通巻第 122 号) pp. 1 9, 1995 年（平成 7 年）9月

檜垣 大助, 吉田 克美, 吉村 典宏, 高橋 透

高知県谷の内地すべり地において，ボーリング・地下水追跡・弾性波探査等の結果から，地すべり斜面の形成 過程を考察した結果，地すべり地は過去の大規模な岩盤すべりで形成されたことがわかった。現在の地質分布や すべり面形態・地すべりの運動形態は斜面形成過程を考えると合理的に解釈される。

\section{斜面崩壊に至るスライドの加速モデル}

「地すべり」Vol. 32, No. 2 (通巻第 122 号) pp. 10 16, 1995 年（平成 7 年）9月

林拙郎, 川遭 洋

三つの仮定を導入することにより，崩壊発生時のスライドの基本モデルを導くことができた。その基本式は次 式で与えられる: $\dot{v}=a v+b v^{2}$ 。ここに, $v$ : 移動速度, $\dot{v}: v$ の時間微分， $a, b$ : 定数である。この式は崩壊に至 る土塊の加速機構を示しており，崩壞予知モデルとしても利用することができる。同時に導かれた摩擦係数 $\mu$ は, Dieterich の結果と類似しており，vが増加すると $\mu$ は低下することを示している。最後に, 摩擦係数 $\mu$ と移 動量 $l, v$ の相互の関係が明らかにされた。

\section{新潟県下における地すべり母岩の力学特性（後編）}

\section{一原位置試験による岩盤力学特性一}

「地すべり」Vol. 32, No. 2（通巻第 122 号）pp. 17〜25, 1995 年（平成 7 年）9 月

野崎保

前編に引き続き, 新潟県下における地すべり母岩の力学特性を, 原位置試験資料に基づいて地層毎に対比・検 討した。また，前編で述べた結果も合わせ総合的な検討を行った。

\section{資料解析によるがけ崩れの崩土の到達距離の予測}

「地すべり」Vol. 32, No. 2 (通巻第 122 号) pp. 26〜31, 1995 年（平成 7 年）9月

大久保 駿, 吉松 弘行, 綱木 亮介

がけ崩れの崩土の到達距離に与える素因及び誘因特性を明らかにするため, 数量化 1 類を用いて解析を行い, 崩壊高, 斜面の縦断形, 連続雨量, 崩壊土量及び斜面の下端の状況が崩土の到達距離の予測において重要な因子 であることを示した。

北海道東部, 網走・北見・津別地域における地すべり地形の特徵と最近の地すべり災害 「地すべり」Vol. 32, No. 2（通巻第 122 号）pp. 32４0,1995 年（平成 7 年）9月 伊藤 陽司

空中写真から 1,765 簓所の地すべり地形を判読し, それらの分布, 規模, 形態や地塊の滑動方向の特徵, 地形・ 地質との関係，最近滑動し災害をもたらした地すべりとの関係を解析した。地すべり地形の約 $79 \%$ は第三紀泥質 岩からなる地域に，そして約 16\%は“緑色岩類”地域に分布する。また，第四紀火砕物地域や火山岩地域にも点在 する。地すべり地形の規模や形態，地塊の滑動方向などの特徴は各地質域での地形，地質構成岩の岩質・岩相や 地質構造を反映している。最近発生した地すべりには地すべり地形を示す斜面が融雪, 豪雨, 地震や斜面末端開 削に伴って再滑動した事例があり，地すべり防災上，地すべり地形の存在や特徵を知ることが重要である。

中国地方東部周辺における地すべり地の土地利用状況について

「地すべり」Vol. 32, No. 2（通巻第 122 号）pp. 41 44, 1995 年（平成 7 年）9月 久保田哲也

従来から土壇水分条件の観点などより, 地すべりの危険箇所判定要因の一つとしての地すべりと土地利用の関 係について議論がなされてきた。しかし，土地利用状況については地域差が大きく，地域の実態をまず把握する 必要がある。本研究では, 地すべり地も多く, 土地利用形態が比較的類似していると思われる中国地方東部周辺 にあたる兵庫県北部，鳥取県，岡山県北部に注目した。この地域において，地域母集団により正規化した相対頻 度“S”を用い, 地すべりと土地利用の関係を研究したところ, 本地域の地すべり地では果樹園・畑, 住宅地, 水 田，コナラ林の S が高く，必ずしも土壌水分の多い土地利用がなされているとは限らない結果が得られた。

地すべり災害と対策技術発展の歴史

一終戦から地すべり等防止法の成立・地すべり学会創立の過程一

「地すべり」Vol. 32, No. 2 (通巻第 122 号) pp. 45〜 52, 1995 年（平成 7 年）9月

福本 安正

Vol. 31，No. 4 において草創から終戦までの地すべり災害と対策技術の発展の歷史を説明したのに続いて，そ の後どのような経過を辿って地すべり技術と調査研究が発展し, そのなかで地すべり等防止法の成立と地すべり 学会の創立をみるに到ったか, そしてまた地すべり法が成立することにより対策技術と調査研究にどのような影 響を与えたかについて明らかにした。 